\title{
Arus Utama Wacana Identitas Penghayat Kepercayaan Pasca Putusan MK di Media Daring Kompas.com
}

\author{
Akil Fitra Sholakodin \\ Departemen Sosiologi, Universitas Indonesia \\ Email : akil.fitra@ui.ac.id
}

\begin{abstract}
Abstrak
Pemberitaan tentang penghayat kepercayaan meningkat drastis sejak Putusan MK Nomor 97/PUU- XIV/2016 di sahkan tahun 2017. Pemberitaan ini tersebar dalam surat kabar, berita televisi dan artikel berita daring seperti Kompas.com, Suara Merdeka, Detik dan Republika. Pemberitaan yang memuat isu sensitif tentang formalisasi identitas penghayat kepercayaan kemudian menjadi perhatian publik. Penelitian ini kemudian difokuskan pada wacana yang muncul dalam pemberitaan identitas penghayat kepercayaan di Kompas.com. Pendekatan penelitian dengan menggunakan metode kualitatif dengan jenis penelitian deskriptif. Sumber data diambil pada artikel berita Kompas.com pada kurun waktu 7 November 2017 sampai Desember 2021. Analisis data dilakukan dengan memadukan Textual Network Analysis (TNA) dan Critical Discourse Analysis (CDA) dengan bantuan software NVIVO, WordlJ dan Gephi. Hasil penelitian diketahui bahwa formalisasi identitas penghayat kepercayaan masih mengalami hambatan dalam konteks diskriminasi dan eksklusi yang masih terjadi dan dilakukan oleh kelompok mayoritas. Kedua, wacana yang terbangun dalam pemberitaan Kompas.com terdiri dari lima pokok yang secara umum mendorong komitmen pemerintah dalam implementasi formalisasi identitas penghayat kepercayaan. Walaupun di dalamnya masih memunculkan kontrol absolut dari negara terkait dengan kemerdekaan dan kesetaraan dalam memeluk kepercayaan dan agama.
\end{abstract}

Kata kunci : penghayat kepercayaan; identitas; putusan MK; TNA; CDA

\section{Mainstream Discourse on the Identity of Believers After the Constitutional Court's Decision on Online Media Kompas.com}

\begin{abstract}
Reports about believers have drastically increased since the Constitutional Court's Decision Number 97/PUU-XIV/2016 was ratified in 2017. This news is spread in newspapers, television news, and online news articles such as Kompas.com, Suara Merdeka, Detik, and Republika. Reports that contain sensitive issues regarding the formalization of the identity of believers then become public attention. This research is then focused on the discourse that appears in the news on the identity of believers in Kompas.com. The research approach uses qualitative methods with descriptive research types. The data source was taken from a news article from Kompas.com from November 7, 2017, to December 2021. Data analysis was carried out by combining Textual Network Analysis (TNA) and Critical Discourse Analysis (CDA) with the help of NVIVO, WordIJ, and Gephi software. The results of the study show that the formalization of the identity of believers in belief still faces obstacles in the context of discrimination and exclusion that still occur and are carried out by the majority group. Second, the discourse that was developed in the Kompas.com news coverage consisted of five main points that in general encouraged the government's commitment to the implementation of the formalization of the identity of believers. Although in it
\end{abstract}


still raises absolute control of the state related to independence and equality in embracing beliefs and religions.

Keywords : indigenous religion; identity; Constitutional Court's Decision; TNA, CDA

\section{LATAR BELAKANG}

Studi-studi terdahulu yang membahas penghayat kepercayaan dalam satu dekade terakhir selalu di dominasi oleh permasalahan sejarah organisasi, ajaran, identitas, eksklusi dan diskriminasi hak-hak dasar pada masyarakat penghayat kepercayaan (Baskoro, 2020; Bustami, 2005; Crouch, 2013; Hamudy \& Rifki, 2020; Hefner, 2021; Hernandi, 2014; Hertz, 2014; Mutaqin, 2014; Ramstedt, 2019) Setidaknya terdapat dua alasan mengapa studi-studi tentang penghayat kepercayaan hanya terfokus pada hal-hal berikut. Pertama, walaupun regulasi-regulasi untuk melindungi dan mengakomodasi kepentingan masyarakat penghayat kepercayaan telah banyak dibuat, tetapi perlakuan diskriminatif terhadap kelompok mereka masih terjadi masyarakat (Baskoro, 2020). Kedua, implementasi regulasi-regulasi berikut masih jauh dari harapan, sehingga eksklusivitas masyarakat penghayat kepercayaan masih terjadi hingga kini.

Ini menunjukkan seolah-olah bahwa penghayat kepercayaan selalu ditampilkan dengan isu-isu sensitif, yang cenderung merepresentasikan kehidupan kelompok yang eksklusif (Hernandi, 2014). Terlebih bila membicarakan isu-isu yang berkaitan dengan identitas dan pelayanan hak yang aturannya belum lama ini di sahkan, yaitu putusan MK (Mahkamah Konstitusi) Nomor 97/PUU- XIV/2016 yang menyamakan kedudukan aliran kepercayaan sama dengan agama di mata hukum (Viri \& Febriany, 2020). Putusan yang dikeluarkan MK berikut diawali dari polemik identitas penghayat kepercayaan di KTP yang tidak dapat mencantumkan agama yang dianut, dan hal ini ditengarai menjadi awal mula diskriminasi dan eksklusi sosial pada kelompok ini.

Sebelum adanya putusan MK berikut, peminggiran pada penghayat kepercayaan bukan hanya terjadi dalam koridor religius-kultural di level masyarakat bawah saja, tetapi juga lewat proses politik di level pemerintah dan negara (AI Qurtuby \& Kholiludin, 2019). Dengan kata lain peminggiran terhadap kelompok penghayat kepercayaan dilakukan di segala level, mulai dari level state sampai society, mulai level marjinalisasi, diskriminasi hingga eksklusi. Studi-studi yang membahas isu peghayat kepercayaan pasca putusan MK sudah banyak dilakukan.. Namun, dari sekian banyak studi yang dilakukan berikut kebanyakan hanya mengulas bagaimana implementasi keputusan MK berikut dan masalah-masalah yang dihadapi di masyarakat. Namun, kendati telah ada studi terdahulu yang mengulas permasalahan penghayat kepercayaan pasca putusan MK, namun kebanyakan pembahasan masih seputar aspek teknis, procedural dan politik birokratis (Adzkiya \& Fadhilah, 2020; Baskoro, 2020; Hamudy \& Rifki, 2020; Maarif et al., 2019; Mahestu, 2018; Mustolehudin \& Muawanah, 2017; Silaban et al., 2020), namun bagaimana diskursus dan wacana penghayat kepercayaan di dunia digital belum banyak dibahas.

Untuk mengisi celah tersebut, studi ini mengambil fokus polemik identitas penghayat kepercayaan pasca putusan MK Nomor 97/PUU- XIV/2016 di salah satu portal berita daring Kompas.com. Media ini dipilih berdasarkan klaster yang telah dielaborasi terkait pembahasan penghayat kepercayaan pasca putusan MK di tahun 2017. Portal berita daring Republika awalnya mendominasi dengan 28 artikel berita (47\%). Disusul Kompas dengan 17 artikel berita (29\%), Suara Merdeka 9 artikel berita (15\%) dan terakhir Detik 4 artikel berita (9\%) (Mustolehudin \& Muawanah, 2017). 
Namun, bila ditelusuri lebih lanjut kawalan isu identitas penghayat kepercayaan pasca putusan MK hingga tahun 2020 didominasi oleh Kompas dengan 61 artikel berita (52\%), Republika 28 artikel berita (26\%), Detik 20 artikel berita (15\%) dan Suara Merdeka 9 artikel berita (5\%). Selain itu menurut website pemeringkat situs populer Alexa (2021), menampilkan Kompas.com di peringkat 6 sebagai situs populer di Indonesia atau menjadi peringkat 4 apabila dilihat dalam kategori portal berita. Data berikut kemudian menjadi pijakan awal mengapa diskursus wacana identitas penghayat kepercayaan difokuskan pada Kompas.com. Selain dipandang punya nama besar sebagai portal berita daring di Indonesia, juga dapat dikategorikan portal berita daring yang mengarus utamakan berita tentang penghayat kepercayaan dengan kuantitas berita yang ditampilkan serta seringnya situs diakses oleh netizen.

Fakta diatas menunjukkan gambaran dinamika yang terjadi pada portal berita daring di Indonesia dalam mengelola isu dan wacana penghayat kepercayaan pasca Putusan MK 2017. Oleh karenanya, sebagai panduan analisis untuk mendalami fenomena berikut, studi ini menggunakan kerangka Textual Network Analysis (TNA) yang dikembangkan Elad Segev dan Critical Discourse Analysis (CDA) oleh Teun Van Dijk. Secara ringkas Textual Network Analysis merupakan interseksi antara Social Network Analysis (SNA) dan Content Analysis (CA). TNA melihat kuantitas dan struktur hubungan antar kata untuk mengidentifikasi kata-kata sentral dalam tubuh tulisan (teks). Selain itu melihat pula klaster-klaster kata yang bertujuan untuk mengungkap makna, topik, tema dan frame pada jaringan kata yang di produksi oleh Big Data (Segev, 2020). Sedangkan Critical Discourse Analysis digambarkan sebagai metode untuk melihat bagaimana struktur dan elemen dalam suatu teks memiliki kekuatan (supporting power) untuk mewacanakan suatu representasi maupun ideologi dibalik teks (Faircloucgh, 2012; Van Dijk, 2014).

Kerangka Textual Network Analysis dan Critical Discourse Analysis belakangan mulai sering dipakai untuk lebih memahami transformasi ruang baru dan wacana yang dibangun dalam beberapa lokus penelitian: Transformasi digital dan diversgensi institusional pada kebijakan level makro (Muhammaditya \& Hardjosoekarto, 2021); sentimen vaksinasi balita di media sosial (Featherstone et al., 2020; Gloria et al., 2018); pengalaman kuliner (Oh \& Kim, 2020); wacana novel (Morris, 2015); industri seni dan hiburan (Fronzetti Colladon \& Naldi, 2019); persepsi publik tentang kesenjangan gender (Stella, 2020); wacana Make America Great Again (Eddington, 2018); gerakan sosial digital (Jiang et al., 2016; Xiong et al., 2019); hingga sampai sebagai alat analisa konstruksi sosial di media massa (Karman, 2014; Pratiwi, 2018; Puji, 2016; Rahmawati, 2020). Namun, sejauh ini belum ada yang menggunakannya dalam membaca karakteristik dan konstruksi sosial dalam wacana yang direproduksi portal berita online tentang penghayat kepercayaan.

Maka dari itu, studi ini akan membahas dua pertanyaan utama; 1). Bagaimanakah dinamika wacana identitas penghayat kepercayaan pasca Putusan MK 2017? dan 2). Bagaimanakah Kompas.com dalam memetakan corpus untuk membentuk dan mengkonstruksi wacana pemberitaan tentang penghayat kepercayaan dalam kerangka Textual Network Analysis dan Critical Discourse Analysis? Tujuan dari penelitian ini adalah menelusuri lebih jauh proses dari bagaimana wacana pemberitaan berikut memengaruhi konstruksi sosial massa pada topik tentang penghayat kepercayaan. 


\section{METODE PENELITIAN}

Penelitian ini menggunakan pendekatan kualitatif dengan jenis penelitian deskriptif yang dilakukan dengan studi data berbasis digital. Penekanan pada studi digital di dasarkan pada perkembangan dan penyebaran internet yang pesat (Palys et al., 2012). Dengan demikian, banyak peluang menarik terutama dari dominasi internet dan implikasinya untuk pengambilan sampel dan pengambilan data pada portal berita daring untuk studi tentang identitas penghayat kepercayaan pasca putusan MK 2017. Unit data yang dianalisis dalam artikel ini adalah kumpulan artikel berita di Kompas.com yang membahas soal isu identitas penghayat kepercayaan pasca Putusan MK 2017 dan terbit antara November 2017 sampai Desember 2020. Terdapat 62 artikel yang dikumpulkan dengan metode scrapping dengan bantuan software NVIVO Capture. Kumpulan data ini validasi dengan 3 langkah: 1). Penentuan sampel corpus (kata yang Menyusun jaringan), 2). Mengidentifikasi aktor kunci dalam jaringan (corpus utama), 3). Mebersihkan daftar corpus yang tidak diperlukan dengan stopword lewat software Word.ij (Granovetter, 2018; Gruzd \& Mai, 2020; Segev, 2020). Sampel data yang sudah ditentukan kemudian di analisis dengan menggunakan pendekatan TNA. Analisis TNA merupakan persimpangan antara analisis SNA dan Content Analysis dengan melihat kualitas dan struktur hubungan antar kata untuk mengidentifikasi kata-kata sentral dalam tubuh teks dan kelompok kata. Kata-kata dalam hal ini dipahami sebagai aktor (corpus) yang terhubung melalui jaringan berupa edges, titik fokus terlihat dari seberapa sering katakata yang dianalisis ini muncul dalam satu jaringan atau lebih (co-appereance/cooccurance) (Annisa, 2021; Segev, 2020). Analisis data dilakukan dengan software Gephi dengan pendekatan modularitas untuk mengetahui seberapa banyak jaringan komunitas tersusun, degree untuk mengetahui jumlah hubungan aktor ke aktor lain dan betweenes centrality untuk mengetahui pengaruh atau power suatu aktor pada aktor lainnya (Blondel et al., 2008; Granovetter, 2018).

Gambar 1: Langkah-langkah analisis TNA

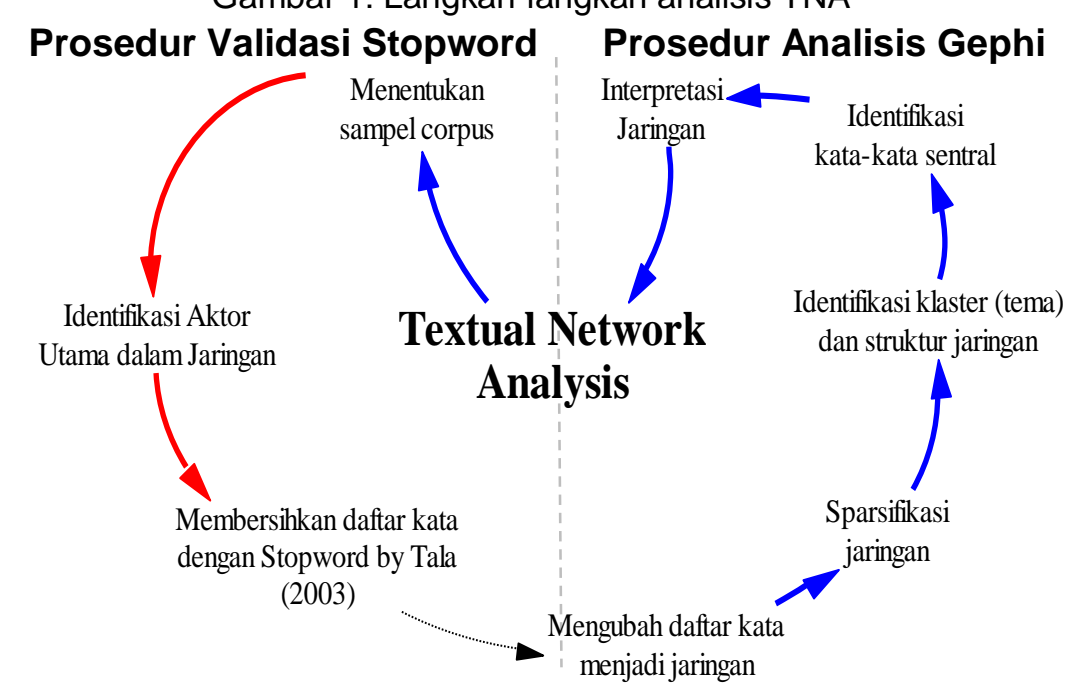

Sumber: Diolah dan diadopsi peneliti dari (Segev, 2020)

Setelah memetakan jaringan kata dalam kerangka TNA, langkah selanjutnya adalah menganalisisnya dalam kerangka analisis wacana kritis (critical discourse analysis). Pendekatan analisis wacana kritis (CDA) yang digunakan dalam penelitian ini menggunakan kerangka dari Teun Van Dijk (2008). Pendekatan CDA Van Dijk dipilih 
dengan alasan sejalan dengan tujuan penelitian, yaitu peneliti ingin melihat dan mendeskripsikan bagaimana penghayat kepercayaan diposisikan dalam wacana pemberitaan Kompas.com pada isu identitas penghayat kepercayaan. Selain itu penggunaan CDA dari Van Dijk secara konseptual lebih cocok untuk menganalisis secara kritis wacana yang dikontruksi Kompas.com. Kerangka CDA dari Van Dijk juga dianggap lebih jernih dalam merinci struktur, komponen dan unsur-unsur wacana (Van Dijk, 2008). Lebih lanjut, dengan pendekatan kognisi sosial kerangka CDA dari Van Dijk juga sangat cocok untuk membahas disparitas kekuasaan pada elemen struktur sosial masyarakat yang melahirkan eksklusi maupun inklusi sosial (Faircloucgh, 2012; Susilo, 2021). Sebagai acuan unit data analisis adalah hasil pemetaan jaringan teks yang telah dilakukan dengan pendekatan TNA. Selanjutnya hasil pemetaan jaringan teks berikut di komparasi dengan komposisi artikel berita Kompas.com tentang identitas penghayat kepercayaan secara utuh untuk melihat sejauh mana kedudukan, ideologi dan keberpihakan Kompas.com dalam wacana pemberitaan identitas penghayat kepercayaan di Indonesia. Berikut gambaran elemen analisis CDA:

Tabel 1: Elemen analisis CDA Van Dijk

\begin{tabular}{lcl}
\hline Struktur wacana & Hal yang diamati & \multicolumn{1}{c}{ Elemen } \\
\hline Struktur makro & $\begin{array}{c}\text { TEMATIK } \\
\text { (apa yang dikatakan) }\end{array}$ & Topik \\
\hline Superstruktur & $\begin{array}{c}\text { SKEMATIK } \\
\text { (bagaimana pendapat di susun dan } \\
\text { dirangkai) }\end{array}$ & Skema \\
\hline Struktur mikro & $\begin{array}{c}\text { SEMANTIK } \\
\text { (makna yang ingin ditekankan pada } \\
\text { teks berita) }\end{array}$ & $\begin{array}{l}\text { Latar, detail, maksud, } \\
\text { praanggapan, nominalisasi }\end{array}$ \\
\hline Struktur mikro & $\begin{array}{c}\text { SINTAKSIS } \\
\text { Struktur mikro }\end{array}$ & $\begin{array}{l}\text { Bentuk kalimat, koherensi, } \\
\text { kata ganti }\end{array}$ \\
\hline Struktur mikro & $\begin{array}{c}\text { STILISTIK } \\
\text { (bagaimana pendapat disampaikan) }\end{array}$ & Leksikon \\
& $\begin{array}{c}\text { RETORIS } \\
\text { (pilihan kata apa yang dipakai) }\end{array}$ & Grafis, metafora ekspresi \\
& (benakanan dilakukan) & \\
\hline
\end{tabular}

Sumber: diadopsi dan diolah peneliti dari (Susilo, 2021)

\section{HASIL DAN PEMBAHASAN}

\section{Dinamika Pengakuan Identitas Penghayat Kepercayaan pasca Putusan MK}

Penganut aliran kepercayaan merupakan suatu kelompok masyarakat yang hidup dan berkembang di masyarakat sudah dalam waktu yang lama, bahkan sebelum Indonesia dibentuk sebagai sebuah negara. Penganut aliran kepercayaan dalam perkembangannya disebut sebagai penghayat kepercayaan (Bustami, 2014; Hernandi, 2016). Sebagai bagian dari warga negara yang memiliki hak dan kewajiban, sudah sepatutnya masyarakat penghayat kepercayaan diperlakukan sama oleh negara. Akan tetapi dalam perkembangannya kelompok penghayat kepercayaan tidak diperlakukan sama dan menerima diskriminasi oleh masyarakat mayoritas, bahkan esklusi oleh negara. Diskriminasi dan eksklusi yang diterima masyarakat penghayat ini beragam bentuknya, seperti kesulitan akses jaminan sosial, pengurusan dokumen kependudukan 
seperti KTP, KK, Akta Menikah, Akta Kelahiran, pengucilan dari lingkungan dan pemaksaan masuk dalam agama resmi (Mutaqin, 2014).

Fokus pada soal identitas yang menjadi hulu dari segala diskriminasi dan eksklusi terhadap masyarakat penghayat kepercayaan (Viri \& Febriany, 2020). Perkembangan paling progesif dalam konteks identitas adalah Putusan MK Nomor 97/PUU- XIV/2016 yang memutuskan kesamaan derajat antara kepercayaan dan agama di mata hukum. Sejalan dengan ini masyarakat penghayat kepercayaan diberikan ruang untuk menuliskan identitas kepercayaan mereka di KTP. Akan tetapi, keputusan ini diikuti dengan persyaratan dan regulasi yang mengisyaratkan relasi kuasa negara atas keyakinan warga negaranya (Hefner, 2021). Melalui seperangkat hukum, pemerintah sebagai penguasa negara menggunakan alat tersebut dalam menentukan apakah kepercayaan atau keyakinan yang di anut oleh warganya dapat di rekognisi dan dilayani. Hal ini memperjelas bahwa sebenarnya diskriminasi oleh masyarakat luas kepada masyarakat penghayat kepercayaan disebabkan oleh eksklusi yang dilakukan oleh negara melalui alat-alat hukum yang mengekangnya.

Secara struktural pengakuan pada penghayat kepercayaan dibagi dalam dua struktur, yaitu struktur akomodatif dan struktur eksklusif. Struktur akomodatif dalam hal ini seperti yang tercantum dalam UUD 1945 pada pasal 28E ayat 2 yang menyatakan "setiap orang berhak atas meyakini kepercayaann, menyatakan pikiran dan sikap sesuai hati nuraninya (AI Qurtuby \& Kholiludin, 2019). UUD 1945 Pasal 29 yang menyatakan "jaminan negara terhadap pilihan keyakinan tiap-tiap penduduk dalam memilih agama dan kepercayaan yang dianut" (Bustami, 2005; Kholik \& Azhari, 2018). Selanjutnya ada UU Nomor 23 Tahun 2006 tentang Adminduk yang selanjutnya dirubah dalam UU Nomor 24 Tahun 2013 yang menyatakan tata cara perkawinan bagi penganut aliran kepercayaan. Selain itu ada regulasi lain yang mengakomodasi eksistensi penghayat kepercayaan, seperti Peraturan bersama Menteri Dalam Negeri dan Menteri Kebudayaan dan Pariwisata Nomor 40-42 Tahun 2009, Permendikbud Nomor 27 Tahun 2016. Terakhir yang paling terbaru adalah Putusan MK Nomor 97/PUU- XIV/2016.

Sedangkan dalam struktur eksklusif seperti yang tercantum dalam UU Nomor 1 Tahun 1965 tentang PNPS: Penyalahgunaan Penodaan Agama yang menjadi hulu dalam eksklusi sosial terhadap penghayat kepercayaan (Bagir et al., 2014). Hal ini terjadi karena krisis politik yang terjadi pada waktu itu karna pemberontakan PKI yang dibumbui isu keagamaan yang kental, sehingga pemerintah melakukan formalisasi agama yang dalam konteks ini tidak me-rekognisi aliran kepercayaan di dalamnya (Picard \& Madinier, 2011). Dampaknya terjadi resistensi kepada penghayat kepercayaan dan memaksa mereka masuk dalam agama-agama yang diresmikan negara (Laelafitrianisahronie, 2021). Selain itu ada Ketetapan MPR Nomor IV/MPR/1978 tentang GBHN yang menegaskan bahwa Kepercayaan Kepada Tuhan Yang Maha Esa bukan merupakan agama. Berikutnya muncul Instruksi Menteri Agama Nomor 4 tahun 1978 tentang kebijakan mengenai Aliran-aliran Kepercayaan yang menyatakan "Departemen Agama tidak lagi mengurusi aliran kepercayaan" (Firdaus, 2019).

Membandingkan dua struktur di atas, dapat dikatakan bahwa pengakuan atas eksistensi masyarakat penghayat kepercayaan mengalami pasang surut. Komponen struktur akomodatif yang lebih banyak dalam praktiknya belum sepenuhnya memberi ruang dan kepastian hukum bagi penghayat kepercayaan sebagai bagian dari warga negara. Faktanya dasar hukum yang sering diberikan ke penghayat kepercayaan lebih banyak pada konteks struktur eksklusif. Negara seakan-akan hadir hanya dalam 
bayang-bayang saja dan masyarakat penghayat seolah-oleh diperlakukan sebagai anak tiri dalam ruang hidup bermasyarakat. Masyarakat penghayat kepercayaan selalu di asosiasikan sebagai outsider community, karena memiliki kebiasaan, adat dan budaya di luar masyarakat umum (Hernandi, 2014).

Putusan MK Nomor 97 yang dikeluarkan pada November 2017 dan menjamin kesetaraan agama dan kepercayaan di mata hukum, serta mengesahkan cantuman kepercayaan dalam KTP menjadi babak baru dalam politik agama serta diskursus formalisasi identitas bagi penghayat kepercayaan. Sejak keputusan ini, penghayat kepercayaan mendapatkan kemudahan dalam mengakses layanan administrasi kependudukan, misalnya pengurusan perkawinan, kelahiran, pindah domisili dan layanan lainnya seperti pekerjaan, asuransi, sekolah dan lain sebagainya (Baskoro, 2020; Laelafitrianisahronie, 2021).

Akan tetapi, Putusan MK tersebut juga menimbulkan permasalahan baru. Pengakuan eksistensi aliran kepercayaan menimbulkan standar baru berupa prasyarat dan aturan untuk mendaftarkan diri dan diakui keberadaannya oleh pemerintah. Mekanismenya adalah harus membuat organisasi secara formal dan mendaftarkan diri ke Direktorat Kepercayaan dan Tradisi yang ada dalam Kemendikbud RI serta masuk dalam pengelolaan Majelis Luhur Kepercayaan Indonesia (MLKI). Selain itu pemerintah juga menetapkan standar pokok dalam menentukan sebuah organisasi adalah aliran kepercayaan, yaitu harus menyembah Tuhan YME, bukan ajaran animisme, ajaran dan lambang kepercayaan tidak serupa dengan agama mana pun. Syarat dan aturan yang ditetapkan berikut menjadi bukti kontrol negara pada setiap keyakinan yang dianut oleh warganya. Seakan-akan negara tidak bisa menerima dengan yakin (take for granted) kebebasan warganya dalam menentukan dan menganut suatu ajaran dan keyakinan (Hernandi, 2014; Laelafitrianisahronie, 2021; Maarif et al., 2019; Sukirno, 2019).

\section{Pemetaan Jaringan Kata pada Berita Identitas Aliran Kepercayaan}

Pada era digital, informasi di produksi melalui jaringan kata-kata yang muncul bersama dalam teks. Teks inilah yang memuat wacana untuk disebarkan ke berbagai media seperti artikel surat kabar, pidato politik, website, status sosial media dan berbagai platform informasi lainnya (Blondel et al., 2008; Segev, 2020; Stella, 2020). Sedangkan jaringan kata-kata adalah wacana yang disusun dan mengandung makna dibaliknya yang selanjutnya dikomunikasikan dalam bentuk informasi (Kang et al., 2017; Martin Jr, 2014; Shin, 2020). Kekuatan jaringan sendiri dapat menunjukkan bagaimana suatu wacana disusun dengan melihat derajat kedekatan antar kata (closeness centrality), derajat pengaruh masing-masing node ke node lainnya (betweenness centrality) dan jumlah hubungan secara langsung antar node (degree) (Granovetter, 2018; Segev, 2020). Dalam konteks wacana identitas penghayat kepercayaan, secara empiris merekam wacana dalam jaringan tekstual di media daring Kompas.com. Dari hasil analisis TNA yang telah dilakukan terdapat 53 corpus (node), 325 edges (ties) dan dikelompokkan dalam 5 komunitas corpus yang saling terhubung dalam satu ikatan jaringan. 
Gambar 1: Sebaran corpus dalam jaringan wacana identitas Penghayat Kepercayaan

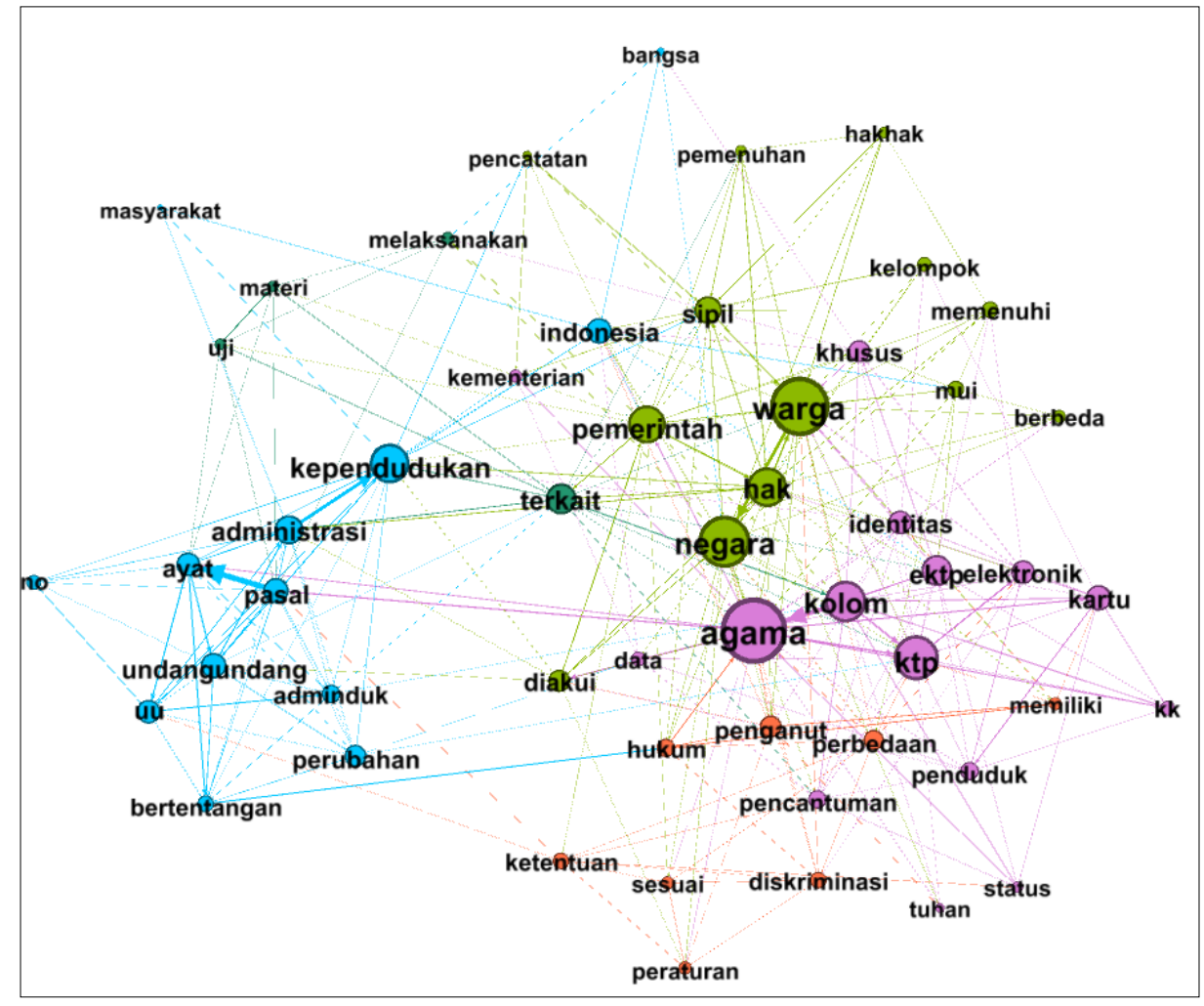

Sumber: Diolah dari hasil analisis TNA (2021)

Berdasarkan modularitas, terdapat 5 komunitas yang terhubung dalam satu ikatan jaringan. Lima komunitas ini terbagi sebagai berikut: 1). Corpus "Agama" dengan modularitas sebesar 28,3\%. 2). Corpus "Negara" dengan modularitas sebesar 24,53\%. 3). Corpus "Kependudukan" dengan modularitas sebesar 24,53\%. 4). Corpus "Penganut" dengan modularitas sebesar 15,69\%. dan 5). Corpus "Terkait" dengan modularitas sebesar $7,55 \%$. Setiap komunitas yang terbagi dalam lima kelompok ini masing-masing membawa wacana sendiri, dengan berdasarkan ukuran modularitas (Segev, 2020). Kelompok pertama dengan modularitas terbesar yaitu sebanyak $28,3 \%$ mengusung wacana "pengisian kolom agama dalam KTP sebagai penganut aliran kepercayaan" yang sudah sejak lama menjadi tujuan masyarakat penghayat kepercayaan. Wacana ini dianggap sangat fundamental berkaitan dengan pemecahan masalah ekslusi dan diskriminasi pada kelompok masyarakatnya. Kelompok kedua dengan derajat modularitas sebesar $24,53 \%$ mengusung wacana "dukungan pemerintah pada hak-hak sipil sebagai warga negara pada masyarakat penghayat kepercayaan yang telah di putuskan oleh MK". Walaupun dalam konteks itu masih ada beberapa resistensi dari Lembaga negara seperti MUI yang membawahi berbagai ormas Islam seperti NU, Muhammadiyah, Persis dan lain sebagainya. Kelompok ketiga dengan derajat modularitas yang sama dengan kelompok kedua, yaitu sebesar 24,53\% mengusung wacana "aspek regulasi dan aturan kependudukan yang secara struktural memberikan pengakuan dan akomodasi pada eksistensi masyarakat penghayat kepercayaan". Aspek struktur akomodatif ini menjadi dasar legislasi dalam uji materi yang di ajukan oleh penggugat kata "agama" dalam pasal 61 UU No. 23 tentang Adminduk 2006. Kelompok keempat dengan derajat modularitas sebesar $15,69 \%$ mengusung wacana "bagaimana eksistensi penghayat kepercayaan dihadang oleh 
diskriminasi yang dilakukan masyarakat mayoritas". Kondisi ini terjadi berkat pemahaman masyarakat yang kurang terhadap kelompok penghayat dan di legitimasi pula oleh struktur esklusif berupa produk hukum masa lalu dan masih berlaku sampai saat ini. Bahkan mungkin sengaja terus digunakan sebagai alat politik guna mengendalikan penganut aliran kepercayaan (state exsclusion). Kelompok kelima dengan derajat modularitas sebesar $7,55 \%$ mengusung wacana "teknis legislasi gugatan ke MK pada tahun 2016", yang berupa uji materi pada Pasal 61 Ayat 1 dan Pasal 64 Ayat 1 UU No. 23 tentang Adminduk 2006, pun pada perubahannya di UU No. 24 Adminduk 2013.

Gambar 2: Jaringan kata-kata Wacana Identitas Penghayat Kepercayaan

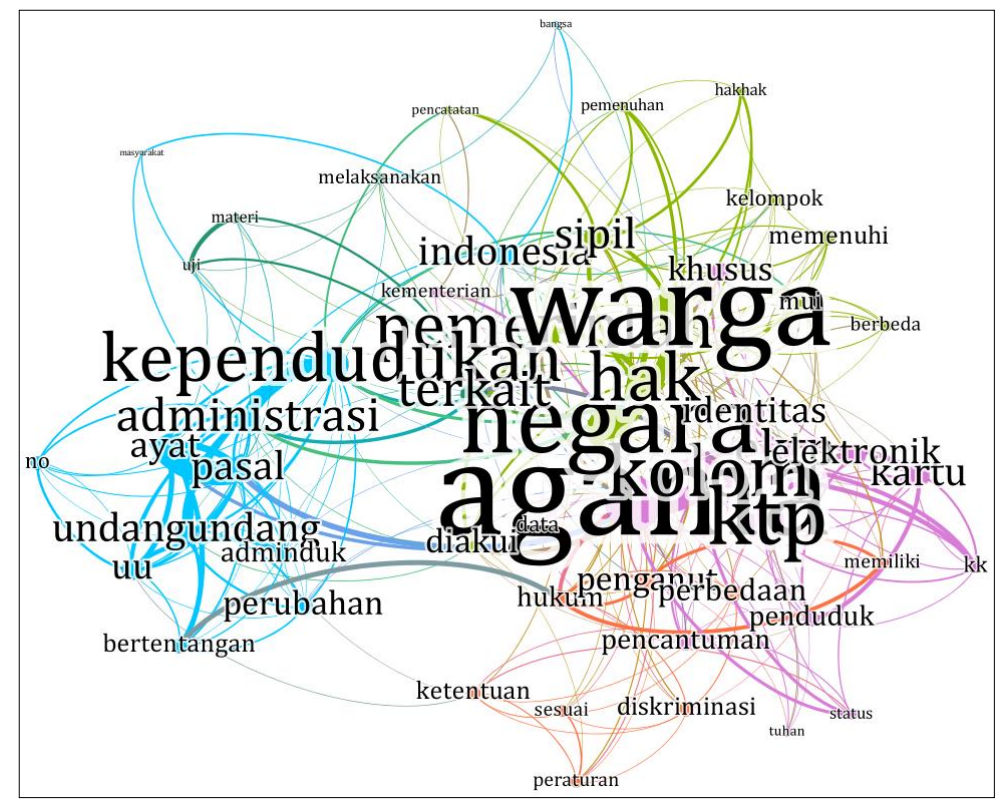

Sumber: Diolah dari hasil analisis TNA (2021)

Wacana formalisasi identitas penghayat kepercayaan disusun berdasarkan keterkaitan dan afiliasi tiap corpus dalam modularitas yang telah di uraikan diatas yang membentuk jaringan (Blondel et al., 2008). Berikutnya Segev (2020) mendefinisikan jaringan sebagai penyusun alamiah dalam pembentukan suatu wacana menjadi informasi. Interaksi antar corpus dan sub-jaringan berikut yang kemudian digunakan sebagai asas penilaian keterpengaruhan wacana dalam membentuk informasi. Derajat keterpengaruhan di ukur dengan hitungan statistik closeness centrality atau kedekatan hubungan corpus satu dengan lainnya, betweennes centrality atau pengaruh satu corpus ke yang lainnya dan jumlah degree yang di miliki tiap corpus atau jumlah relasasi tiap corpus ke corpus lainnya (relasi masuk dan keluar) (Blondel et al., 2008; Segev, 2020; Stella, 2020).

Tabel 2: Jumlah ties terbanyak dan pengaruh tiap node

\begin{tabular}{llclll}
\hline No & Corpus (Node) & $\begin{array}{l}\text { Jumlah } \\
\text { (ties) }\end{array}$ & Koneksi & $\begin{array}{l}\text { Kedekatan (Closeness } \\
\text { centrality) }\end{array}$ & $\begin{array}{l}\text { Pengaruh } \\
\text { centrality) }\end{array}$ \\
\hline 1 & Agama & 37 & 0,590909 & 0,217954 & \\
2 & Warga & 33 & 0,530612 & 0,125478 \\
3 & Negara & 29 & 0,536082 & 0,100438 \\
4 & KTP & 25 & 0,460177 & 0,62997 \\
5 & Hak & 23 & 0,448276 & 0,48685 \\
\hline
\end{tabular}

Sumber: Diolah dari hasil penelitian (2021) 
Berdasarkan tabel dan uraian diatas, identifikasi corpus difokuskan pada 5 corpus dengan relasi (ties) terbanyak. Pertama corpus "Agama" dengan jumlah relasi 37 terbagi dalam 18 relasi masuk (in degree) dan 19 relasi keluar (out degree). Angka closeness centrality diketahui sejumlah 0,590909 dan betweenness centrality diketahui sejumlah 0,217954 yang berarti "Agama" menjadi corpus inti dalam wacana identitas penghayat kepercayaan. Kedua corpus "Warga" dengan jumlah relasi 33 terbagi dalam 21 relasi masuk dan 12 relasi keluar. Angka closeness centrality diketahui sejumlah 0, 530612dan i diketahui sejumlah 0,125478 yang berarti "Warga" menjadi corpus kedua dengan relasi dan pengaruh yang kuat dalam wacana identitas penghayat kepercayaan. Ketiga corpus "Negara" dengan jumlah relasi 29 yang terbagi dalam 12 relasi masuk dan 17 relasi keluar. Angka closeness centrality diketahui sejumlah 0, 536082 dan betweenness centrality diketahui sejumlah 0,100438 yang berarti corpus ketiga dengan pengaruh yang kuat, utamanya dalam membentuk jaringan dengan wacana dukungan pemerintah terhadap Putusan MK. Keempat corpus "KTP" dengan jumlah relasi 25 yang terbagi dalam 14 relasi masuk dan 11 relasi keluar. Angka closeness centrality diketahui sejumlah 0,460177dan betweenness centrality diketahui sejumlah 0,62997 yang berarti menjadi corpus keempat dengan penagruh dan kedekatan terbesar. Terutama dalam Menyusun wacana teknis pencantuman kepercayaan terhadap Tuhan YME dalam kolom agama di KTP, serta menghubungkannya dengan wacana eksklusi yang diberikan masyarakat mayoritas pada penghayat kepercayaan. Kelima corpus "Kolom" dengan jumlah relasi 23 terdiri dari 13 relasi masuk dan 10 relasi keluar. Angka closeness centrality diketahui sejumlah 0,448276 dan betweenness centrality diketahui sejumlah 0, 48685 yang berarti menjadi corpus dengan pengaruh besar kelima. Terutama dalam Menyusun wacana hak penghayat kepercayaan sebagai warga negara tidak diberikan dan cenderung di acuhkan sebelum Putusan MK Nomor 97 disahkan.

\section{Wacana Identitas Aliran Kepercayaan di Kompas.com dalam Kerangka CDA}

Pemetaan jaringan melalui kerangka TNA diatas menghasilkan lima klaster struktur corpus yang mengkonstruksi wacana pemberitaan identitas penghayat kepercayaan. Kelima corpus yang dominan ini terdiri dari agama, warga negara, negara, KTP dan hak. Setiap struktur corpus atau teks yang telah terkonstruksi berikut perlu di elaborasi lebih dalam untuk melihat struktur wacana yang ditampilkan oleh Kompas.com. struktur wacana ini dibedah dengan menggunakan pendekatan kognisi sosial lewat bantuan analisis analisis wacana kritis (CDA) Teun Van Dijk. Fokus pembedahan dilakukan dengan melihat elemen-elemen wacana yang terdiri dari tiga bagian, yaitu struktur makro, struktur mikro dan suprastruktur yang ada dalam teks di tubuh setiap artikel berita (Faircloucgh, 2012; Hamad, 2004; Van Dijk, 2014).

Pembedahan teks (corpus) dalam kerangka CDA dimulai dengan melihat struktur makro dalam susunan teks yang telah di petakan. Struktur makro sendiri dimaknai sebagai pemaknaan secara umum terhadap teks dilihat dari wacana yang dimunculkan dalam tema tertentu (Drabu, 2018; López Maestre, 2020; Van Dijk, 2008). Hal yang diamati dalam struktur makro fokus pada aspek apa yang dikatakan (tematik) dalam berita yang di analisis, pertanyaan ini selanjutnya dapat dilihat dalam topik berita (Faircloucgh, 2012; Susilo, 2021; Van Dijk, 2014). Melihat dari hasil TNA dan keseluruhan wacana berita terkait identitas penghayat kepercayaan pasca putusan MK memuat wacana besar tentang formalisasi identitas penghayat kepercayaan sebagai penganut aliran kepercayaan dalam KTP. 
Hal ini tidak mengherankan bila merujuk pada lima klaster jaringan teks (corpus) dari TNA yang telah dilakukan. Kelima jaringan teks berikut yakni agama, warga negara, negara, KTP dan hak merepresentasikan pilihan-pilihan teks yang inklusif terhadap hak sipil penganut aliran kepercayaan. Selain itu kelima teks kuat dalam jaringan ini pada masing-masing klasternya selalu memosisikan penghayat kepercayaan sebagai kelompok ter-subordinasi oleh negara. Fakta ini didukung dalam susunan teks yang selalu memuat frasa "diskriminasi", "pemenuhan", "diakui" dan "berbeda". Frasa-frasa berikut secara tidak langsung dimaksudkan penulis-penulis Kompas.com untuk mengartikulasikan bahwa penghayat kepercayaan merupakan kelompok yang terdiskriminasi, kebutuhan dan hak administrasinya belum terpenuhi serta tidak diakui keberadaannya.

Pada tahap selanjutnya, pembedahan wacana tentang identitas penghayat kepercayaan dilakukan pada elemen suprastruktur. Elemen ini merupakan struktur wacana yang memiliki relasi yang disebabkan karena analisis antara kerangka teori teks dengan bagian yang disusun secara sistematis dalam teks (Faircloucgh, 2012; Featherstone et al., 2020; Van Dijk, 2014). Hasil pengamatan suprastruktur terfokus pada bagaimana pendapat disusun dan dirangkai (skematik) (Susilo, 2021; Van Dijk, 2008). Pada elemen suprastruktur ini unit analisis di bagi menjadi empat bagian, yakni summary yang berada di judul, lead, isi dan cerita keseluruhan berita dan penutup (Askew \& Williams, 2021). Berdasarkan 62 artikel berita Kompas.com dan pemetaan jaringan kata di TNA, pembahasan suprastruktur dibagi dalam empat konsep besar yaitu, dsikriminasi dan eksklusi sosial pada penghayat kepercayaan, putusan MK Nomor 97/PUU- XIV/2016 yang menyamakan kedudukan agama dan kepercayaan, pro-kontra terhadap hasil putusan MK berikut dan tindak lanjut pada tahap implementasi formalisasi identitas penghayat kepercayaan di KTP.

Dari uraian empat konsep besar yang ada pada suprastruktur berikut, Kompas.com mengisyaratkan perdebatan politik agama yang menarik ulur posisi kelompok penghayat kepercayaan. Kompas.com satu sisi ingin memperlihatkan secara gamblang bagaimana eksklusi negara terhadap penghayat berdampak sangat besar pada segala aspek kehidupannya. Ruang-ruang eksklusi dimulai pada level masyarakat dengan membiarkan stigma penghayat sebagai liyan terus bergulir. Selanjutnya ruang eksklusi ini kembali berlaku pada level layanan administratif negara, dengan pembedaan pengurusan segala keperluan sipilnya. Pada sisi yang lain dengan segala sisi eksklusi dan diskriminasi yang diterima kelompok penghayat kepercayaan memberikan celah untuk melawan pada level konstitusi dengan mengajukan gugatan ke MK. Upaya-upaya ini dilukiskan dengan baik oleh Kompas.com, dengan kuantitas berita hasil putusan MK hingga beberapa ulasan.

Dalam elemen ketiga, pembedahan wacana identitas penghayat kepercayaan dilakukan pada struktur mikro. Analisis pada elemen struktur mikro dibagi dalam empat bagian, yaitu semantik yang menguraikan makna yang ingin ditekankan pada teks (Latar, detail, maksud, praanggapan, nominalisasi), sintaksis yang mendeskripsikan bagaimana pendapat disampaikan (Bentuk kalimat, koherensi, kata ganti), stilistik yang beroperasi pada pilihan kata apa yang dipakai (leksikon), retoris yang menekankan pada bagaimana dan dengan cara apa penekanan dilakukan (grafis, metafora ekpresi) (Philo, 2007; Susilo, 2021; Van Dijk, 2014).

Secara semantik latar yang disorot adalah ketika formalisasi identitas kepercayaan pada penghayat kepercayaan lewat putusan MK direspon publik. Ulasan tentang 
putusan MK ini di reproduksi berulang-ulang dengan mengambil posisi dari berbagai sudut, mulai dari dampak putusan $\mathrm{MK}$, teknis pelaksanaan sampai pada riwayat diskriminasi. Muara dari unsur semantik ini dimaksudkan untuk memosisikan kelompok penghayat kepercayaan yang ter-eksklusi dan terdiskriminasi, sehingga negara perlu memberikan perlindungan serta memberikan haknya seperti warga negara yang lainnya. Poin-poin berikut hampir ditemui pada setiap artikel yang dikumpulkan. Dalam unsur pra anggapan wacana mikro dikonstruksikan dengan mengulas pendapat aktor-aktor terkait. Mulai dari pendapat aktor mayoritas dari kelompok muslim terkait kesetaraan kepercayaan dan agama yang diwakili kelompok Nahdlatul Ulama (NU) yang ditampilkan lebih menerima dengan prasyarat tertentu. Deskripsi resistensi dijelaskan pula dengan pendapat-pendapat dari Majelis Ulama Indonesia (MUI) lewat ketua umum $\mathrm{KH}$. Ma'ruf Amin.

Sedangkan pada unsur sintaksis terdapat tiga unsur penting, yakni koherensi, bentuk kalimat dan kata ganti. Sisi koherensi ditampilkan dengan dua bentuk, yaitu koherensi sebab-akibat dan koherensi pembeda. Kemudian pada unsur bentuk kalimat dari 62 artikel yang dikumpulkan lebih banyak bentuk kalimat deduktif ditampilkan daripada kalimat induktif. Sedangkan untuk kata ganti dominasi terletak pada penggunaan kata ganti jamak seperti mereka, para, kami dan kita. Hal ini tidak terlepas sebagai upaya untuk menampilkan penghayat kepercayaan sebagai kelompok liyan. Representasi semacam itu yang diupayakan Kompas.com untuk mendorong inklusifitas pada penghayat kepercayaan. Sehingga perlu kontrol negara dengan pendekatan struktural untuk memulihkan hak-hak penghayat kepercayaan. Untuk kata ganti tunggal cukup sedikit ditemukan, mengingat penggunaannya hanya terbatas pada pendapat tokoh-tokoh yang ditampilkan memberikan statement pro-kontra pada wacana ini.

Gambar 3: Bagan CDA Identitas Penghayat Kepercayaan di Kompas.com

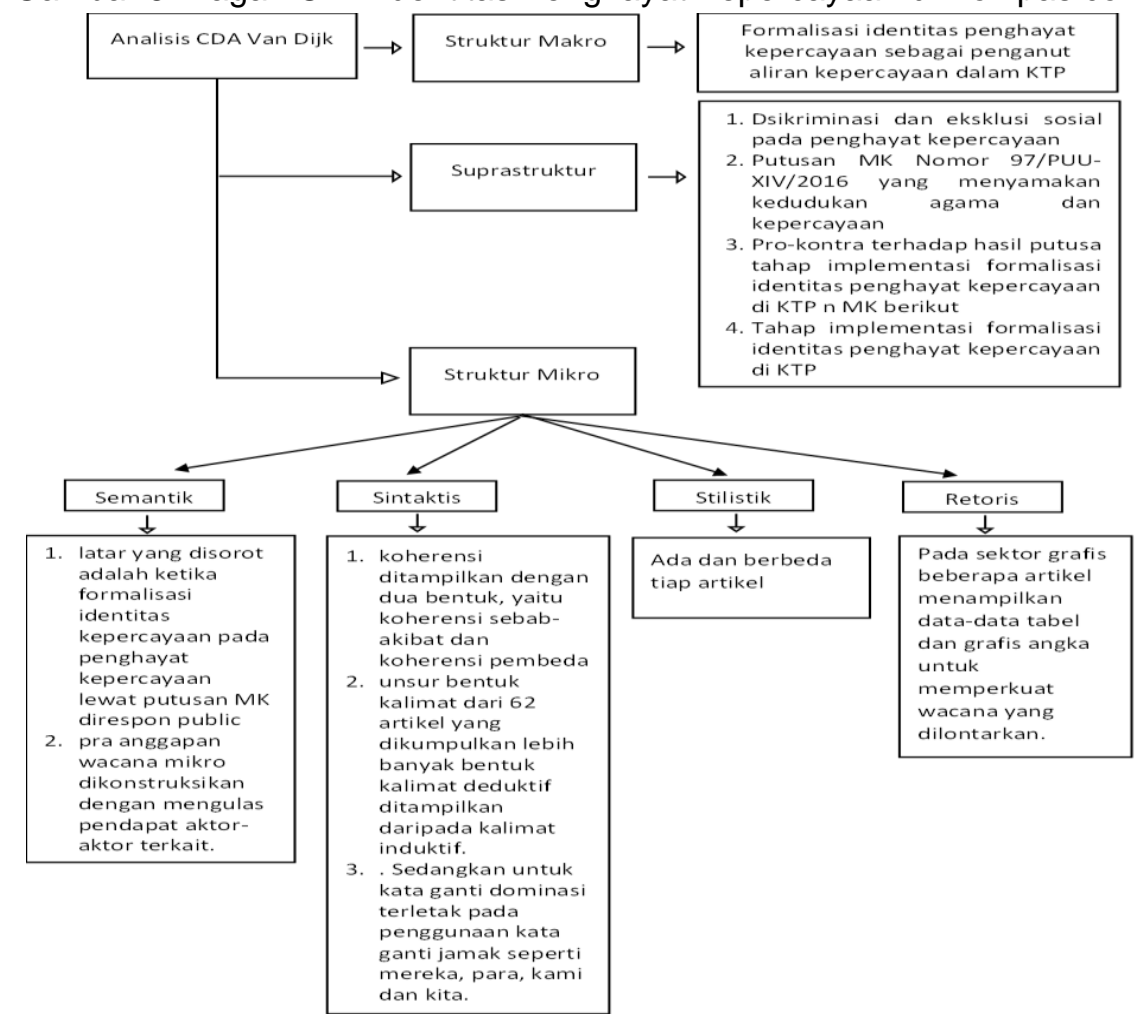

Sumber: diolah peneliti dari hasil penelitian (2021) 
Secara stilistik dan retoris berbeda pada tiap artikel, tergantung pada konteks pemberitaan yang produksi. Pada sektor grafis beberapa artikel menampilkan data-data tabel dan grafis angka untuk memperkuat wacana yang dilontarkan. Secara visual image ditemui beberapa metafora seperti gambar lampu petromak dengan logo Pancasila yang dimaksudkan untuk merepresentasikan bagaimana birokratisasi diskriminasi yang berujung pada intoleransi. Di sisi yang lain beberapa foto kegiatan penghayat kepercayaan ditampilkan dalam headline artikel sebagai ilustrasi dan penjelas.

\section{KESIMPULAN}

Dari hasil penelitian ini dapat disimpulkan bahwa: pertama, wacana formalisasi identitas penghayat kepercayaan dengan mencantumkan kata "Kepercayaan terhadap Tuhan YME" belum terimplementasi dengan baik. Walaupun dalam konteks ini gugatan atas Pasal 61 Ayat 1 dan Pasal 64 Ayat 1 UU Nomor 23 Tentang Adminduk sudah dikabulkan oleh MK dengan mengesahkan Putusan MK Nomor 97/PUU- XIV/2016 pada tanggal 7 November 2017. Hambatan ini berupa kesulitan akses dalam mengurus dokumen kependudukan seperti KTP, KK, Akta Kelahiran dan Akta Kematian. Selain itu juga pada sektor lainnya seperti pekerjaan, asuransi dan pendidikan. Polemik pencantuman kepercayaan dalam kolom agam di KTP pun juga menjadi politik agama baru dari negara. Secara tidak sadar aturan yang sebenarnya menyetarakan posisi kepercayaan dengan agama ini dianggap menjadi cara baru negara untuk mengontrol dan men-standarisasi apa yang boleh diyakini dan dipeluk oleh warga negara terkait dengan agama dan kepercayaan.

Kedua, hasil analisis TNA tentang formalisasi identitas penghayat kepercayaan dalam kolom agama di KTP memunculkan 5 wacana pokok yaitu: 1). Kewajiban dan keharusan pemerintah untuk menyetarakan aliran kepercayaan dengan agama. Secara langsung juga mengisyaratkan penghapusan diskriminasi dan eksklusi yang sudah biasa diterima oleh masyarakat penghayat kepercayaan. 2). Dukungan pemerintah dan komitmen pelayanan yang sama bagi penghayat kepercayaan pasca putusan MK. Sekaligus upaya perlindungan terhadap resistensi yang muncul dari kalangan agama resmi, utamanya dari lembaga negara seperti MUI yang terdiri dari ormas Islam. Juga memberikan pemahaman dan sosialisasi Putusan MK berikut kepada kalangan agama resmi. 3). Penghayat memiliki dasar hukum dalam konteks pengakuan negara pada eksistensinya, seperti yang termuat dalam struktur akomodatif dalam bentuk UUD, UU, Surat Keputusan Menteri dan Permen. 4). Hambatan-hambatan yang dialami oleh masyarakat penghayat kepercayaan berupa diskriminasi dari kelompok mayoritas, yang kemudian melatarbelakangi uji materi dan berujung pada kesetaraan yang tercantum di Putusan MK 27. 5). Uraian secara teknis legislasi yang dilakukan dalam gugatan Pasal 61 Ayat 1 dan Pasal 64 Ayat 1 UU Nomor 23 tentang Adminduk yang menjadi dasar subordinasi negara dan mayoritas pada masyarakat penghayat kepercayaan.

\section{UCAPAN TERIMAKASIH}

Penulis mengucapkan banyak terimakasih kepada teman diskusi dan mentor dalam menulis artikel ini, terutama kepada Pembimbing Prof. Iwan Gardono Sudjatmiko Ph.D yang telah banyak memberi masukan dan saran. Serta kepada Dr. Abdul Latif Bustami, M.Si. dari Universitas Negeri Malang yang telah mengenalkan penulis pada isu Aliran Kepercayaan di Indonesia. 


\section{DAFTAR PUSTAKA}

Adzkiya, U., \& Fadhilah, I. (2020). Inklusi Sosial Penghayat Kepercayaan; Upaya Mendorong Hak Warga Negara Penganut Kepercayaan Sedulur Sikep Kudus. AtTaqaddum, 12(1), 91. https://doi.org/10.21580/at.v12i1.5622

Al Qurtuby, S., \& Kholiludin, T. (2019). Agama dan Kepercayaan Nusantara.

Annisa, R. (2021). Digital feminist activism : Analyzing Jakarta Feminist as a collective identity, resources, network, information dissemination, and mobilization Aktivisme feminis digital: Menganalisis Jakarta Feminist sebagai identitas. 1998(Suwana 2020), 175-186.

Askew, R., \& Williams, L. (2021). Rethinking enhancement substance use: A critical discourse studies approach. International Journal of Drug Policy, 95. https://doi.org/10.1016/j.drugpo.2020.102994

Bagir, Z. A., Hefner, R. W., \& Ali-fauzi, I. (2014). Mengelola Keragaman dan Kebebasan Beragama di Indonesia: Sejarah, Teori dan Advokasi [Managing Diversity and Religious Freedom in Indonesia: History, Theory and Advocacy]. CRCS UGM, 1138.

Baskoro, A. (2020). Mewujudkan Social Inclusion: Kontribusi Satunama terhadap Penghayat Kepercayaan di Yogyakarta. Panangkaran: Jurnal Penelitian Agama Dan Masyarakat, 3(2), 181. https://doi.org/10.14421/panangkaran.2019.0302-03

Blondel, V. D., Guillaume, J. L., Lambiotte, R., \& Lefebvre, E. (2008). Fast unfolding of communities in large networks. Journal of Statistical Mechanics: Theory and Experiment, 2008(10). https://doi.org/10.1088/1742-5468/2008/10/P10008

Bustami, A. L. (2005). Tuhan Agama Mu Apa? Realisasi Kuasa Republik dan Keyakinan Keagamaan. In Kepercayaan Terhadap Tuhan Yang Maha Esa Dalam Sebuah Realita (Vol. 1, Issue 1, pp. 1-50). Departemen Kebudayaan dan Pariwisata.

Bustami, A. L. (2014). Sejarah Direktorat Pembinaan Kepercayaan terhadap Tuhan Yang Maha Esa dan Tradisi. Direktorat Kepercayaan Terhadap Tuhan Yang Maha Esa.

Crouch, M. (2013). Shifting conceptions of state regulation of religion: The Indonesian Draft Law on Inter-religious Harmony. Global Change, Peace and Security, 25(3), 265-282. https://doi.org/10.1080/14781158.2013.764859

Drabu, O. (2018). Who is the Muslim? Discursive representations of the Muslims and Islam in Indian prime-time news. Religions, 9(9). https://doi.org/10.3390/rel9090283

Eddington, S. M. (2018). The Communicative Constitution of Hate Organizations Online: A Semantic Network Analysis of "Make America Great Again." Social Media and Society, 4(3). https://doi.org/10.1177/2056305118790763

Faircloucgh, N. (2012). Critical Discourse Analysis. The Routledge Handbook of Applied Linguistics, 7(1), 445-459. https://doi.org/10.4324/9780203835654

Featherstone, J. D., Ruiz, J. B., Barnett, G. A., \& Millam, B. J. (2020). Exploring childhood vaccination themes and public opinions on Twitter: A semantic network analysis. Telematics and Informatics, 54. https://doi.org/10.1016/j.tele.2020.101474

Firdaus, A. (2019). )Politik Rekognisi Penghayat (Sarasehan Nasional Penghayat). In IJIR.

Fronzetti Colladon, A., \& Naldi, M. (2019). Predicting the performance of TV series through textual and network analysis: The case of Big Bang Theory. PLoS ONE, 14(11), 1-21. https://doi.org/10.1371/journal.pone.0225306

Gloria, K. G., Ewing, N. S., Mackey, L., JTSchlitt, Marathe, A., Abbas, K., \& Swarup, S. (2018). Semantic Network Analysis of Vaccine Sentiment in Online Social Media. Vaccine, 176(1), 139-148. https://doi.org/10.1016/j.vaccine.2017.05.052.Semantic

Granovetter, M. S. (2018). The Strength of Weak Ties. In Inequality in the 21st Century. https://doi.org/10.4324/9780429499821-43

Gruzd, A., \& Mai, P. (2020). Going viral: How a single tweet spawned a COVID-19 conspiracy theory on Twitter. Big Data and Society, 7(2). 
https://doi.org/10.1177/2053951720938405

Hamad, I. (2004). Konstruksi Realitas Politik Dalam Media Massa (Studi Pesan Politik Dalam Media Cetak Pada Masa Pemilu 1999). Makara Human Behavior Studies in Asia, 8(1), 21. https://doi.org/10.7454/mssh.v8i1.77

Hamudy, M. I. A., \& Rifki, M. S. (2020). Civil Rights of the Believers of Unofficial Religions (Penghayat Kepercayaan) in Pekalongan District. Jurnal Antropologi: Isu-Isu Sosial Budaya, 22(1), 48. https://doi.org/10.25077/jantro.v22.n1.p48-59.2020

Hefner, R. W. (2021). Islam and institutional religious freedom in indonesia. Religions, 12(6). https://doi.org/10.3390/rel12060415

Hernandi, A. (2014). Eksistensi, Organisasi, dan Kehidupan Penghayat Kepercayaan terhadap Tuhan Yang Maha Esa. 1-11.

Hernandi, A. (2016). Nilai-nilai Ajaran Kepercayaan terhadap Tuhan YME sebagai Rujukan Pembentukan Karakter Bangsa. MLKI, 30,1-11.

Hertz, J. C. (2014). Sekularisme dan Hak-Hak Individu dalam Usaha Melawan Diskriminasi Rasial dan Etnis di Indonesia. Antropologi Indonesia, 0(72), 58-72. https://doi.org/10.7454/ai.v0i72.3474

Jiang, K., Barnett, G. A., \& Taylor, L. D. (2016). Dynamics of culture frames in international news coverage: A semantic network analysis. International Journal of Communication, 10, 3710-3736.

Kang, G. J., Ewing-Nelson, S. R., Mackey, L., Schlitt, J. T., Marathe, A., Abbas, K. M., \& Swarup, S. (2017). Semantic network analysis of vaccine sentiment in online social media. Vaccine, 35(29). https://doi.org/10.1016/j.vaccine.2017.05.052

Karman, K. (2014). Media Massa dan Konstruksi Realitas (Analisis Framing Terhadap Pemberitaan SKB Menteri Tentang Ahmadiyah di Indonesia pada Suratkabar Harian Suara Pembaruan dan Republika). In Jurnal Studi Komunikasi dan Media (Vol. 17, Issue 2, p. 173). https://doi.org/10.31445/jskm.2013.170205

Kholik, S., \& Azhari, A. (2018). Tinjauan Yuridis Normatif Tentang Pengisian Kolom Agama Dalam Identitas Kependudukan Berdasarkan Pasal 61 Ayat (2) Undang Undang Nomor 23 Tahun 2006 Tentang Administrasi Kependudukan Dikaitkan dengan Keberadaan Komunitas Dayak Hindhu - Buddha Bumi Segan. HERMENEUTIKA: Jurnal IImu Hukum, 2(2). https://doi.org/10.33603/hermeneutika.v2i2.1564

Laelafitrianisahronie. (2021). Antara Agama dan Kepercayaan :Menguji Praktik Kewargaan Ingenious Paguyuban Ngesti Tunggal (Pangestu). In The Asia Foundation.

López Maestre, M. D. (2020). Gender, Ideology and Conceptual Metaphors: Women and the Source Domain of the Hunt. Complutense Journal of English Studies, 28, 191206. https://doi.org/10.5209/cjes.68355

Maarif, S., Mubarok, H., Sahroni, L. F., \& Roessusita, D. (2019). Merangkul Penghayat Kepercayaan Melalui Advokasi Inklusi Sosial: Belajar dari Pengalaman Pendampingan.

Mahestu, G. (2018). Emic Analysis Towards Penghayat Kepercayaan Dynamics in the Democratic Era. E3S Web of Conferences, 73, 4-7. https://doi.org/10.1051/e3sconf/20187314016

Martin Jr, T. E. (2014). Framing the discourse of leadership: An analysis of the social consruction of leadership within communication, business and higher education. The University of Alabama.

Morris, A. (2015). This product made from postconsumer content: Narrative recycling and new novelistic economies. Criticism, 57(1), 1-22. https://doi.org/10.13110/criticism.57.1.0001

Muhammaditya, N., \& Hardjosoekarto, S. (2021). Divergensi Transformasi Digital Pengelolaan Bank Soal Era Masyarakat 5.0. Jurnal Pendidikan Dan Kebudayaan, 6, 54-77.

Mustolehudin, M., \& Muawanah, S. (2017). Polemik Pengisian Kolom Agama di KTP Jurnal Sosiologi Pendidikan Humanis $180 \mid 182$ 
bagi Penganut Aliran Kepercayaan (Studi Pada Media Cetak, On-Line, dan Media Sosial Bulan November 2014) Polemics of Filling Out Column on Identity Card For Faith Followers (A Study of Print, On-Line, and Social Media. Jurnal SMART (Studi Masyarakat, Religi, Dan Tradisi), 3(2), 231-242. https://doi.org/10.18784/smart.v3i2.494

Mutaqin, Z. Z. (2014). Penghayat, orthodoxy and the legal politics of the state: The survival of Agama Djawa Sunda (Madraisism) in Indonesia. Indonesia and the Malay World, 42(122), 1-23. https://doi.org/10.1080/13639811.2014.870771

Oh, M. (Moon), \& Kim, S. (Sam). (2020). Dimensionality of ethnic food fine dining experience: An application of semantic network analysis. Tourism Management Perspectives, 35(July). https://doi.org/10.1016/j.tmp.2020.100719

Palys, T., Columbia, B., \& Atchison, C. (2012). Qualitative Research in the Digital Era: Obstacles and Opportunities. International Journal of Qualitative Methods, 352367.

Philo, G. (2007). Can discourse analysis successfully explain the content of media and journalistic practice? Journalism 8(2). https://doi.org/10.1080/14616700601148804

Picard, M., \& Madinier, R. (2011). The politics of religion in Indonesia: Syncretism, orthodoxy, and religious contention in Java and Bali. In The Politics of Religion in Indonesia: Syncretism, Orthodoxy, and Religious Contention in Java and Bali. https://doi.org/10.4324/9780203817049

Pratiwi, A. (2018). Konstruksi realitas dan media massa (analisis framing pemberitaan LGBT di republika dan BBC news, model Robert N. Entman). Jurnal Bahasa, Peradaban Dan Informasi Islam, 19(1), 1-22.

Puji, S. (2016). Konstruksi Sosial Media Massa Puji Santoso Dosen Komunikasi Fakultas IImu Sosial dan IImu Politik Universitas Muhammadiyah Sumatera Utara. Al-Balagh, $1(1), 34$.

Rahmawati, A. Y. (2020). Terorisme dalam Konstruksi Media Massa. Jrmdk, 2(1), 3851.

Ramstedt, M. (2019). Politics of Taxonomy in Postcolonial Indonesia: Ethnic Traditions between Religionisation and Secularisation. Historical Social Research, 44(3), 264289. https://doi.org/10.12759/hsr.44.2019.3.264-289

Segev, E. (2020). Textual network analysis. Detecting prevailing themes and biases in international news and social media copy 2.pdf. Sociology Compass.

Shin, Y. (2020). What can tripartite semantic network analysis do for media framing research? Communication and Society, 33(1), 121-137. https://doi.org/10.15581/003.33.1.121-137

Silaban, R., Gustiranda, P., \& Agung, U. D. (2020). Kebangkitan Hak-Hak Sipil Penghayat Kepercayaan Parmalim Pasca Pasal 61 Ayat (1) Putusan Mahkamah Konstitusi Nomor 97/Puu-Xiv/2016 di Kota Medan. 2(1), 75-84.

Stella, M. (2020). Text-mining forma mentis networks reconstruct public perception of the STEM gender gap in social media. PeerJ Computer Science, 6. https://doi.org/10.7717/PEERJ-CS.295

Sukirno, S. (2019). Politik Hukum Pengakuan Hak atas Administrasi Kependudukan Bagi Penganut Penghayat Kepercayaan. Administrative Law and Governance Journal, 2(2). https://doi.org/10.14710/alj.v2i2.268-281

Susilo, D. (2021). Analisis Wacana Kritis Van Dijk: Sebuah Model dan Tinjauan Kritis pada Media Daring. In Unitomo Press (Issue July, pp. 1-23).

Van Dijk, T. (2008). Discourse and Context. In Cambridge University Press.

Van Dijk, T. (2014). Discourse and Knowledge: A Sociocognitive Approach. In Cambridge University Press.

Viri, K., \& Febriany, Z. (2020). Dinamika Pengakuan Penghayat Kepercayaan di Indonesia. Indonesian Journal of Religion and Society, 2(2), 97-112. https://doi.org/10.36256/ijrs.v2i2.119 
Xiong, Y., Cho, M., \& Boatwright, B. (2019). Hashtag activism and message frames among social movement organizations: Semantic network analysis and thematic analysis of Twitter during the \#MeToo movement. Public Relations Review, 45(1). https://doi.org/10.1016/j.pubrev.2018.10.014 